\title{
PENGEMBANGAN MULTIMEEDIA PEMBELAJARAN INTERAKTIF INSTALASI MOTOR LISTRIK KELAS XI TITL SMK SWASTA DWIWARNA MEDAN
}

\author{
Horas Karlos Pasaribu $^{1}$; Sahat Siagian ${ }^{2}$ \\ ${ }^{1,2}$ Pendidikan Teknik Elektro, Fakultas Teknik Universitas Negeri Medan \\ $\underline{{ }^{1} \text { horaskarlospasaribu@gmail.com, }{ }^{2} \text { sahatsgn@gmail.com }}$
}

\begin{abstract}
This research is generally a research that aims to develop learning multimedia. Multimedia learning is very important in the learning process, good learning multimedia is very effective in the teaching and learning process. Researchers try to develop interactive learning multimedia that can be used in the form of interactive CDs, using several software consisting of Adobe Flash CS6, Adobe Photoshop CS5. Aims to make it easier for students to understand the lesson and also make it easier for educators to deliver lessons. Multimedia learning in this study uses the ADDIE model by using five stages in it which was adapted by Sugiyono. The target of this research is the Expert Lecturer at the State University of Medan. Tests on interactive multimedia by media validators, material validators, and user/acceptance validators showed that the resulting learning multimedia was good with a score of 4.33 for material validation, a score of 4.35 for media validation, and a score of 4.29 for user/acceptance validation. .
\end{abstract}

\section{Keywords: Interactive Multimedia Development, Adobe Flash CS6 Software, Electric Motor Installation.}

\begin{abstract}
Abstrak
Penelitian ini secara umum merupakan penelitian yang bertujuan untuk mengembangkan multimedia pembelajaran. Multimedia pembelajaran termasuk hal yang sangat penting dalam proses pembelajaran, multimedia pembelajaran yang baik sangat efektif digunakan dalam proses belajar mengajar. Peneliti mencoba mengembangkan multimedia pembelajaran interaktif yang dapat digunakan dalam bentuk CD interaktif, menggunakan beberapa software yang terdiri dari Adobe Flash CS6, Adobe Photoshop CS5. Bertujuan untuk memudahkan peserta didik dalam memahami pelajaran dan juga memudahkan pendidik dalam menyampaikan pelajaran. Multimedia pembelajaran pada penelitian ini menggunakan model ADDIE denggan menggunakan lima tahap di dalamnya yang diadaptasi oleh Sugiyono. Sasaran penelitian ini adalah Dosen Ahli Universitas Negeri Medan. Pengujian terhadap multimedia interaktif oleh validator media, validator materi, dan validator user/akseptansi menunjukkan bahwa multimedia pembelajaran yang dihasilkan baik dengan skor 4,33 untuk validasi materi, skor 4,35 untuk validasi media, dan skor 4,29 untuk validasi user/akseptansi.
\end{abstract}

\section{Kata kunci: Pengembangan Multimedia Interaktif, Software Adobe Flash CS6, Instalasi Motor Listrik.}

\section{PENDAHULUAN}

Pendidikan merupakan sebuah kebutuhan penting bagi manusia untuk dapat berkembang sekaligus membedakan manusia dengan makhluk hidup lainnya. Perkembangan ilmu pengetahuan dan teknologi semakin pesat, dimana saat ini menuntut manusia untuk terus mengembangkan wawasan dan kemampuan diberbagai bidang. Saat ini berbagai kemudahan telah ditunjukkan oleh perkembangan dan kemajuan teknologi. Untuk mengimbangi perkembangan dan kemajuan suatu negara perlu adanya kegiatan belajar mengajar. Melalui pendidikan, kegiatan belajar mengajar akan berlangsung dan menghasilkan berbagai pengetahuan. Perkembangan teknologi di bidang peralatan listrik memberikan peluang yang besar untuk meningkatkan kebutuhan tenaga kerja yang kompeten di bidang teknik instalasi tenaga listrik (TITL). Pemakaian Multimedia pembelajaran dalam proses belajar mengajar dapat membangkitkan keinginan dan minat yang baru, membangkitkan motivasi dan rangsangan kegiatan belajar, dan bahkan membawa pengaruh-pengaruh psikologis terhadap siswa. Multimedia pengajaran juga dapat membantu siswa meningkatkan pemahaman, menyajikan data dengan menarik dan terpercaya, memudahkan penafsiran data, dan memadatkan informasi (Azhar Arsyad, 2011: 16). 
Dari hasil observasi yang telah dilakukan, penggunaan Multimedia pada proses pembelajaran adalah solusi yang dapat digunakan di dalam kelas untuk menumbuhkan minat belajar siswa, karena proses penerapan pembelajaran masih kurang efektif untuk menarik perhatian siswa. Multimedia pembelajaran interaktif sangat penting digunakan untuk membuat pembelajaran menjadi sangat menarik dan tidak membosankan. Untuk memaksimalkan peningkatan pembelajaran diperlukan peningkatan aktivitas siswa sehingga dapat meningkatkan pemahaman mereka terhadap materi pembelajaran yang disampaikan.

SMK Swasta Dwiwarna Medan merupakan salah satu SMK yang ada di Medan yang memiliki beberapa program keahlian. Salah satu program keahliannya adalah Teknik Instalasi Tenaga Listrik (TITL). Instalasi Motor Listrik adalah salah satu mata pelajaran yang diberikan di SMK Swasta dwiwarna medan. Berdasarkan hasil observasi yang telah dilakukan pada mata pelajaran Instalasi Motor Listrik di SMK Swasta Dwiwarna Medan dan wawancara dengan Bapak Sandro Simatupang. S. Pd selaku Guru di kelas tersebut, bahwa kebanyakan siswa masih memiliki nilai yang rendah ataupun belum mencapai Kriteria Ketuntasan Minimal (KKM).

Oleh karena itu, ditinjau dari hasil observasi awal di SMK Swasta Dwiwarna, yaitu dengan mendengar pendapat dari Guru bidang studi Instalasi Motor Listrik bahwasannya pemanfaatan media dan proyektor sebagai alat komunikasi antara guru dan siswa saat proses pembelajaran masih kurang, pemanfaatan media pembelajaran sangat mendukung sebelum pembelajaran praktek dilakukan. Sesuai kebutuhan menggunakan media pembelajaran, kompetensi dasar yang digunakan pada media adalah 3.7 sampai 3.8 dengan materi komponen elektromekanik, pengasutan dan pengontrolan motor induksi tiga fasa. Pada media pembelajaran akan disajikan simulasi-simulasi, video, serta penjelasan materi Instalasi Motor Listrik untuk mendukung proses pembelajaran serta tujuan utama untuk menumbuhkan minat dan motivasi belajar siswa. Dari penjelasan peneliti kepada siswa, semua siswa di dalam kelas sangat setuju dan tertarik jika pembelajaran menggunakan multimedia pembelajaran di dalam kelas, karena multimedia pembelajaran menjadi langkah awal untuk melatih siswa dalam mempelajari sebuah materi pembelajaran.

\section{Belajar dan Pembelajaran}

Belajar merupakan suatu proses usaha dalam pembelajaran yang dilakukan oleh individu secara sadar untuk memperoleh perubahan tingkah laku. Menurut Suprihatiningrum (2013) memberikan defenisi luas bahwa belajar merupakan perubahan tingkah laku yang di dapat dari pengalaman (latihan) dalam interaksinya dengan lingkungan. Belajar merupakan suatu proses mengembangkan daya pikir, dan merupakan suatu informasi bagi siswa. Menurut Surya (2013) “belajar dapat diartikan sebagai suatu proses yang dilakukan individu untuk memperoleh perubahan perilaku baru secara keseluruhan, sebagai hasil dari pengalaman individu itu sendiri dalam berinteraksi dengan lingkungannya".

\section{Hakekat Pengembangan}

Pengembangan adalah kegiatan ilmu pengetahuan dan teknologi yang bertujuan memanfaatkan kaidah dan teori ilmu pengetahuan yang telah terbukti kebenarannya untuk meningkatkan fungsi, manfaat, dan aplikasi ilmu pengetahuan dan teknologi yang telah ada atau menghasilkan teknologi baru. Pengembangan adalah suatu proses yang dipakai untuk mengembangkan dan memvalidasi produk pendidikan. Penelitian ini mengikuti suatu langkah-langkah secara siklus. Langkah penelitian atau proses pengembangan ini terdiri atas kajian tentang temuan penelitian produk yang akan dikembangkan, mengembangkan produk berdasarkan temuan-temuan tersebut, melakukan uji coba lapangan sesuai dengan latar di mana produk tersebut akan dipakai, dan melakukan revisi terhadap hasil uji lapangan (Punaji Setyosari, 2013: 222-223).

Pada hakikatnya pengembangan adalah upaya pendidikan baik formal maupun non formal yang dilaksanakan secara sadar, berencana, terarah, teratur, dan bertanggung jawab dalam rangka memperkenalkan, menumbuhkan, membimbing, mengembangkan suatu dasar kepribadian yang seimbang, utuh, selaras, pengetahuan, keterampilan sesuai dengan bakat, keinginan serta kemampuan kemampuan sebagai bekal atas prakarsa sendiri untuk menambah, meningkatkan, mengembangkan diri ke arah tercapainya martabat, mutu dan kemampuan manusiawi yang optimal dan pribadi mandiri (Iskandar Wiryokusumo dalam Afrilianasari ; 2014). 


\section{Hakekat Multimedia}

Kata Multimedia berasal dari bahasa Latin medium yang berarti perantara atau pengantar. Lebih lanjut, Rahardjo menyebutkan, media merupakan sarana penyalur pesan atau informasi belajar yang hendak disampaikan oleh sumber pesan kepada sasaran atau penerima pesan tersebut. Dalam kegiatan belajar-mengajar, sumber pesan adalah guru dan penerima pesan adalah murid. Sementara itu, Association for Educational Communication and Technology (AECT) mendefinisikan media sebagai segala bentuk yang digunakan untuk proses penyaluran informasi. Sedangkan Oemar Hamalik mendefinisikan, Multimedia sebagai teknik yang digunakan dalam rangka lebih mengefektifkan komunikasi antara guru dan murid dalam proses pendidikan dan pengajaran di sekolah. Media pembelajaran merupakan perantara atau alat untuk memudahkan proses belajar mengajar agar tercapai tujuan pengajaran secara efektif dan efisien. Robert Hanick dkk yang disitir oleh Benni Agus Pribadi mendefinisikan media adalah sesuatu yang membawa informasi antara sumber (source) dan penerima (receiver) informasi. Masih dalam sudut yang sama, Kemp dan Dayton mengemukakan, peran media dalam proses komunikasi sebagai alat pengirim (transfer) yang mentransmisikan pesan dari pengirim (sender) kepada penerima pesan atau informasi (receiver).

\section{Multimedia Interaktif}

Multimedia Interaktif merupakan suatu alat yang dilengkapi dengan alat kontrol yang dapat dioperasikan oleh penggunanya dalam memilih sesuatu yang dikehendaki. Contoh Multimedia interaktif adalah: multimedia pembelajaran inter-aktif (pembelajaran berbasis multimedia interaktif), aplikasi game dan lain-lain. Model Pembelajaran Berbasis Multimedia Interaktif Pada dasarnya, pembelajaran diselenggarakan dengan harapan agar mahasiswa mampu menangkap/menerima, memproses, menyimpan, serta mengelu-arkan informasi yang telah diolahnya. Media yang dapat mengakomodir persyaratanpersyaratan tersebut adalah komputer. Komputer mampu menyajikan informasi yang dapat berbentuk video, audio, teks, grafik, dan animasi (simulasi). Sebagai contoh, pada pembelajaran matematika, beberapa topik yang sulit disampaikan secara konvensional atau sangat membutuhkan akurasi yang tinggi, dapat dilaksanakan dengan bantuan teknologi komputer/ multimedia, seperti grafik dan diagram dapat disajikan dengan mudah dan cepat, penampilan gambar, warna, visualisasi, video, animasi dapat mengoptimalkan peran indra dalam menerima informasi ke dalam sistem informasi (Kariadinata, 2010).

Berdasarkan penjelasan tersebut dapat ditarik kesimpulan bahwa pembelajaran berbasis multimedia adalah pembelajaran yang menggunakan bantuan komputer/ multimedia dengan memanfaatkan android. Menurut Nandi (2006), terdapat beberapa format sajian pembelajaran berbasis multimedia Interaktif seperti berikut:

1. Model tutorial merupakan salah satu model pembelajaran interaktif yang digunakan dalam proses belajar mengajar dengan menggunakan software berupa program komputer berisi materi mata kuliah. Tutorial dalam program multimedia interaktif ditujukan sebagai pengganti manusia sebagai instruktur pada kenyataannya,

2. Model Drills merupakan salah satu bentuk model pembelajaran interaktif berbasis komputer (CBI) yang bertujuan memberikan pengalaman belajar yang lebih kongkret melalui penyediaan latihan-latihan soal untuk menguji penampilan siswa melalui kecepatan menyelesaikan soal yang diberikan program,

3. Model simulasi pada dasarnya merupakan salah satu strategi pembelajaan yang bertujuan memberikan pengalaman secara nyata melalui penciptaan tiruan bentuk pengalaman yang mendekati suasana sebenarnya dan berlangsung dalam suasana yang tanpa resiko, dan

4. Model Instructional Games adalah salah satu model pembelajaran dengan menggunakan multimedia.

\section{Adobe Flash CS6}

Adobe Flash atau yang dikenal pada awalnya sebagai Macromedia Flash adalah salah satu perangkat lunak komputer yang merupakan produk unggulan dari Adobe Systems. Aobe flash CS6 juga pengembangan dari adobe dibawahnya seperti CS3, CS4, CS5, yang sudah sering kita lihat tampilannya. Adobe Flash ini digunakan untuk membuat gambar vektor maupun animasi gambar. Adobe Flash merupakan sebuah program yang didesain khusus oleh Adobe untuk keperluan pembangunan situs web yang interaktif dan dinamis sehingga sangat cocok untuk membuat animasi dan bitmap yang sangat menarik. 
Adanya software Adobe Flash CS6 telah mempermudah untuk membuat media pembelajaran berbasis multimedia interaktif. Kemampuan program Adobe Flash CS6 dalam pembuatan presentasi multimedia mendukung pembuatan animasi secara langsung, mendukung penyisipan multimedia seperti gambar, suara, dan video ke animasi yang dibuat.

\section{Hakekat Pengembangan Multimedia Pembelajaran}

Kriteria yang paling utama dalam pemilihan media bahwa media harus disesuaikan dengan tujuan pembelajaran atau kompetensi yang ingin dicapai. Contoh: bila tujuan atau kompetensi peserta didik bersifat menghafalkan kata-kata tentunya media audio yang tepat untuk digunakan. Jika tujuan atau kompetensi yang dicapai bersifat memahami isi bacaan maka media cetak yang lebih tepat digunakan. Kalau tujuan pembelajaran bersifat motorik (gerak dan aktivitas), maka media film dan video bisa digunakan. Di samping itu, terdapat kriteria lainnya yang bersifat melengkapi (komplemen), seperti: biaya, ketepatgunaan; keadaan peserta didik; ketersediaan; dan mutu teknis. Rudi Bretz dalam Bukhari mengklasifikasika media atas karakteristik utamanya suara, bentuk visual (gambar, garis dan simbol) dan gerak. Di samping itu, ia juga membedakan media tranmisi dan media rekaman. Atas dasar inilah Bertz mengggolongkan semua media itu menjadi 8 kelas: 1) Media audio visual gerak, 2) Media audio visual diam, 3) Media audio semi gerak, 4) Media visual gerak, 5) Media visual diam, 6) Media semi gerak, 7) Media audio, dan 8) Media cetak. Sementara itu, Oemar Hamalik (1986), Djamarah (2002) dan Sadiman, dkk (1986), mengelompokkan media ini berdasarkan jenisnya ke dalam beberapa jenis, yaitu : a. Media auditif, yaitu media yang hanya mengandalkan kemampuan suara saja, seperti tape recorder. b. Media visual, yaitu media yang hanya mengandalkan indra penglihatan dalam wujud visual. c. Media audiovisual, yaitu media yang mempunyai unsur suara dan unsur gambar. Jenis media ini mempunyai kemampuan yang lebih baik, dan media ini dibagi ke dalam dua jenis 1) Audiovisual diam, yang menampilkan suara dan visual diam, seperti film sound slide. 2) Audiovisual gerak, yaitu media yang dapat menampilkan unsur suara dan gambar yang bergerak, seperti film, video cassete dan VCD. Sementara itu, selain media-media tersebut di atas, di lembaga pendidikan kehadiran perangkat komputer telah merupakan suatu hal yang harus dikondisikan dan disosialisasikan untuk menjawab tantangan dan kemajuan ilmu pengetahuan dan teknologi.

\section{METODE}

Penelitian ini bertujuan untuk mengetahui kelayakan media pembelajaran dan apakah sudah memenuhi syarat dalam pembelajaran. Penelitian ini menggunakan software Adobe flash CS6 sebagai media interaktif pada mata pelajaran Instalasi motor listrik. Dengan bantuan aplikasi ini kita dapat membuat suatu animasi yang berhubungan dengan materi. Peserta didik dapat berinteraksi secara langsung dengan media pembelajaran ini, sehingga peserta didik dapat memahami materi pembelajaran.

Tersediannya media pembelajaran interaktif pada mata pelajaran akan memberikan pengalaman dalam meningkatkan motivasi belajar. Media interaktif yang akan digunakan menampilkan beberapa materi yang membutuhkan penggunaan multimedia di dalamnya. Materi akan disampaikan dalam bentuk teks, gambar, dan animasi/video yang dimaksudkan untuk menunjang proses pembelajaran.

Model ADDIE merupakan model yang digunakan pada proses perancangan dan pembuatan multimedia pembelajaran. Model ADDIE memiliki lima tahap dalam perancangannya yaitu analisis, design, pengembangan, implementasi dan evaluasi.

Multimedia pembelajaran yang telah selesai dibuat akan diuji kelayakannya kepada ahli media dan ahli materi untuk memberikan penilaian pada multimedia yang dibuat. Dari hasil validasi tersebut kita akan mengetahui apakah media yang kita buat layak dan telah memenuhi syarat sebagai multimedia pembelajaran.

Berdasarkan uraian di atas, selanjutnya media yang telah dibuat diuji kelayakannya kepada pengguna yaitu siswa/i kelas XI TITL SMK Swasta Dwiwarna Medan.

Adapun langkah-langkah atau tahap yang harus dilakukan adalah

1. Analisa atau mengidentifikasi kebutuhan

2. Analisis data kebutuhan

3. Perancangan media

4. Media/Membangun Media.

5. Uji coba produk. 
Penelitian ini dilaksanakan di SMK Swasta Dwiwarna Medan, Jl. Gedung Arca No.52, Teladan Bar.,Kec. Medan Kota, Kota Medan, Kelas XI Teknik Instalasi Tenaga Listrik (TITL) Pada Semester Genap Tahun ajaran 2019/2020. Subjek Penelitian ini adalah siswa/i kelas XI Teknik Instalasi Tenaga Listrik SMK Swasta Dwiwarna Medan beserta satu orang guru mata pelajaran Instalasi Motor Listrik. Teknik pengumpulan data pada penelitian ini yaitu menggunakan instrumen yaitu instrumen validasi untuk ahli materi, instrumen validasi untuk ahli media pembelajaran, dan instrumen uji coba produk untuk siswa SMK.

Data angket yang diperoleh akan dianalisa dengan langkah-langkah sebagai berikut:

1. angket yang telah diisi responden, diperiksa kelengkapan jawabannya, kemudian disusun sesuai dengan kode responden.

2. mengkuantitatifkan pertanyaan dengan memberikan skor sesuai dengan bobot yang telah ditentukan sebelumnya.

3. membuat tabulasi data.

Kemudian ditransformasikan kedalam tabel berikut:

Tabel 1. Interval Kriteria Penilaian

\begin{tabular}{|c|c|c|c|}
\hline NO & INTERVAL SKOR & \multicolumn{2}{|c|}{ INTERPRETASI } \\
\hline 1 & $1,00-2,49$ & Tidak Baik & Tidak Layak \\
\hline 2 & $2,50-3,32$ & Kurang Baik & Kurang Layak \\
\hline 3 & $3,33-4,16$ & Baik & Layak \\
\hline 4 & $4,17-5,00$ & Sangat Baik & Sangat Layak \\
\hline
\end{tabular}

\section{HASIL DAN PEMBAHASAN}

\section{Hasil}

Berdasarkan analisis kebutuhan lapangan menghasilkan multimedia interaktif berbasis Adobe Flasih CS6. Penelitian dan pengembangan ini dilakukan di SMK Swasta Dwiwarna Medan. Penelitian ini menggunakan metode penelitian ADDIE dari tahap 1 sampai tahap 5 yang mengadopsi dari Sugiyono. Adapun langkah-langkah pengembangan produk dijelaskan sebagai berikut:
a. Potensi dan masalah
b. Pengumpulan data
c. Desain Produk

\section{Validasi Ahli Materi}

Kebenaran materi di validasi oleh dosen Pendidikan Teknik Elektro UNIMED yaitu Bapak Dr. Agus Junaidi, S.T.,M.T. dan Bakti Dwi Waluyo, S.Pd.,M.T. Hasil validasi ahli materi terhadap produk multimedia interaktif berbasis Adobe Flash CS6 pada pelajaran Instalasi motor listrik ditampilkan pada table 2 berikut ini.

Tabel 2. Hasil Validasi Ahli Materi

\begin{tabular}{|c|c|c|c|c|c|c|c|}
\hline No & \multicolumn{2}{|c|}{ Aspek Materi } & $\begin{array}{l}\text { Panduan } \\
\text { dan } \\
\text { Informasi }\end{array}$ & $\begin{array}{l}\text { Konten/Maten } \\
\text { Multimedia }\end{array}$ & Evaluasi & Total & $\begin{array}{l}\text { Mean skor } \\
\text { \& Penilaian }\end{array}$ \\
\hline \multirow[b]{2}{*}{1} & \multirow[b]{2}{*}{ Penilai 1} & Jh skor & 16 & 53 & 33 & 102 & 4,25 \\
\hline & & $\begin{array}{l}\text { Jh } \\
\text { butir }\end{array}$ & 4 & 12 & 8 & 24 & $\begin{array}{l}\text { Sangat } \\
\text { layak }\end{array}$ \\
\hline \multirow[b]{2}{*}{2} & \multirow[b]{2}{*}{ Penilai 2} & Jh skor & 17 & 52 & 37 & 106 & 4,4 \\
\hline & & $\begin{array}{c}\text { Jh } \\
\text { butir }\end{array}$ & 4 & 12 & 8 & 24 & $\begin{array}{l}\text { Sangat } \\
\text { layak }\end{array}$ \\
\hline 3 & \multicolumn{2}{|c|}{ Total Skor } & 33 & 105 & 70 & & 215 \\
\hline 4 & \multicolumn{2}{|c|}{ Mean Skor } & 4,12 & 4,37 & 4,37 & & 4,33 \\
\hline 5 & \multicolumn{2}{|c|}{ Hasil Penilaian } & Layak & Sangat layak & $\begin{array}{l}\text { Sangat } \\
\text { layak }\end{array}$ & \multicolumn{2}{|c|}{ Sangat layak } \\
\hline
\end{tabular}


Data dari analisis hasil validasi ahli materi dapat dilihat pada Gambar.1 berikut:

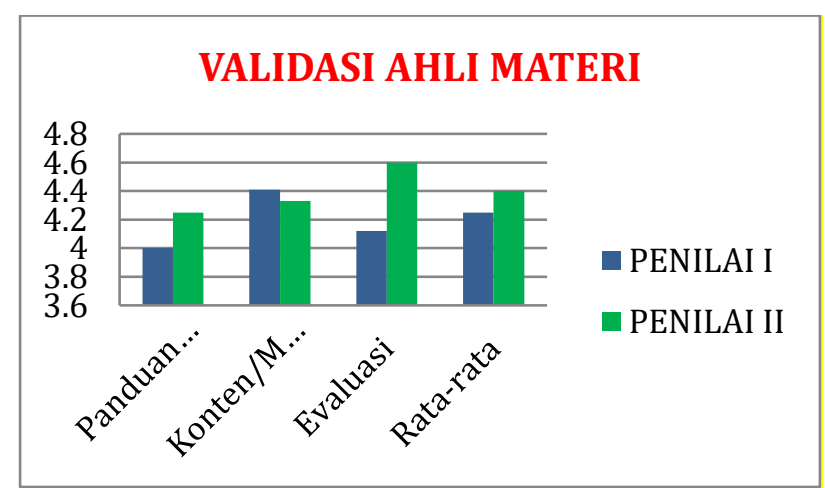

Gambar 1. Hasil Validasi Ahli Materi

\section{Validasi Ahli Media}

Adapun ahli media terdiri dari 2 dosen UNIMED yaitu Bapak Fahmy Syahputra, S.Kom., M.Kom. dan Bapak M. Aulia R. S.,ST.,MT. Validasi terhadap hasil pengembangan multimedia interaktif berbasis Adobe Flash CS6 pada mata pelajaran instalasi motor listrik oleh ahli media dapat dilihat dalam table 4.2 berikut:

Tabel 3. Hasil Validasi Ahli Media

\begin{tabular}{|c|c|c|c|c|c|c|c|}
\hline No & \multicolumn{2}{|c|}{ Aspek Media } & $\begin{array}{l}\text { Panduan } \\
\text { dan } \\
\text { Informasi }\end{array}$ & $\begin{array}{l}\text { Kinerja } \\
\text { Program }\end{array}$ & $\begin{array}{l}\text { Sistematika, } \\
\text { Estetika, } \\
\text { dan Prinsip } \\
\text { Rekabentuk }\end{array}$ & Total & $\begin{array}{l}\text { Mean skor } \\
\& \text { Penilaian }\end{array}$ \\
\hline \multirow[b]{2}{*}{1} & \multirow[b]{2}{*}{ Penilai 1} & Jh skor & 14 & 45 & 105 & 164 & 4,31 \\
\hline & & Jh butir & 3 & 10 & 25 & 38 & $\begin{array}{l}\text { Sangat } \\
\text { Layak }\end{array}$ \\
\hline \multirow[b]{2}{*}{2} & \multirow[b]{2}{*}{ Penilai 2} & Jh skor & 13 & 44 & 110 & 167 & 4,39 \\
\hline & & Jh butir & 3 & 10 & 25 & 38 & $\begin{array}{l}\text { Sangat } \\
\text { layak }\end{array}$ \\
\hline 3 & \multicolumn{2}{|l|}{ Total Skor } & 27 & 89 & 215 & & 331 \\
\hline 4 & \multicolumn{2}{|c|}{ Mean Skor } & 4,5 & 4,4 & 4,3 & & 4,35 \\
\hline 5 & \multicolumn{2}{|c|}{ Hasil Penilaian } & $\begin{array}{l}\text { Sangat } \\
\text { layak }\end{array}$ & $\begin{array}{c}\text { Sangat } \\
\text { layak }\end{array}$ & $\begin{array}{l}\text { Sangat } \\
\text { layak }\end{array}$ & \multicolumn{2}{|c|}{ Sangat layak } \\
\hline
\end{tabular}

Data dari analisis hasil validasi ahli media dapat dilihat pada Gambar 2 berikut:

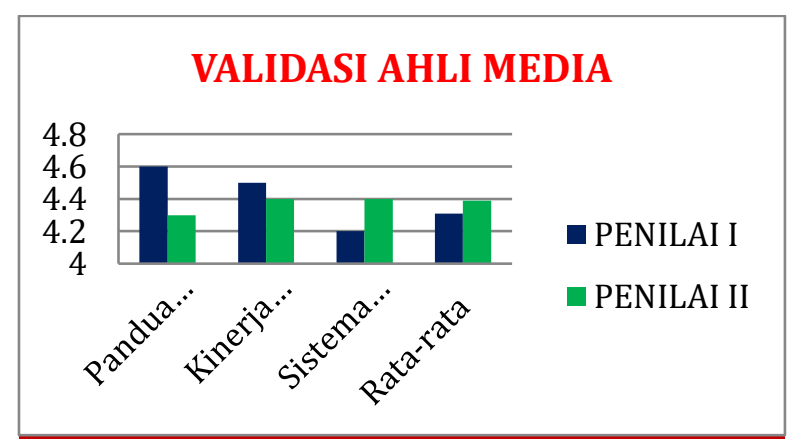

Gambar 2. Hasil Validasi Ahli Media 


\section{Validasi dari User/Akseptansi}

Hasil validasi akseptansi dari Ibu Tansa Trisna Astono Putri, S.Kom.,M.T.I. terhadap produk multimedia interaktif berbasis Adobe Flash CS6 pada pelajaran Instalasi motor listrik ditampilkan pada table 4 berikut ini.

Tabel 4. Hasil Validasi User/Akseptansi

\begin{tabular}{|c|c|c|c|c|c|c|c|c|c|}
\hline No & \multicolumn{2}{|c|}{ Aspek Media } & $\begin{array}{l}\text { Panduan } \\
\text { dan } \\
\text { Informasi }\end{array}$ & $\begin{array}{l}\text { Materi } \\
\text { media }\end{array}$ & Evaluasi & $\begin{array}{c}\text { Desain } \\
\text { dan } \\
\text { Fasilitas } \\
\text { Media }\end{array}$ & $\begin{array}{c}\text { Efek } \\
\text { Pedagogi }\end{array}$ & Total & $\begin{array}{c}\text { Mean skor } \\
\& \\
\text { Penilaian }\end{array}$ \\
\hline \multirow[b]{2}{*}{1} & \multirow[b]{2}{*}{ Penilai } & $\begin{array}{c}\text { Jh } \\
\text { skor }\end{array}$ & 16 & 54 & 22 & 45 & 22 & 159 & 4,29 \\
\hline & & $\begin{array}{l}\text { Jh } \\
\text { skor }\end{array}$ & 4 & 13 & 5 & 10 & 5 & 37 & $\begin{array}{l}\text { sangat } \\
\text { layak/tingg } \\
\text { i }\end{array}$ \\
\hline 2 & \multicolumn{2}{|c|}{ Mean Skor } & 4 & 4,1 & 4,4 & 4,5 & 4,4 & & 4,29 \\
\hline 3 & \multicolumn{2}{|c|}{ Hasil Penilaian } & $\begin{array}{l}\text { layak/ } \\
\text { tinggi }\end{array}$ & $\begin{array}{l}\text { layak/ } \\
\text { tinggi }\end{array}$ & $\begin{array}{l}\text { sangat } \\
\text { layak/ } \\
\text { tinggi }\end{array}$ & $\begin{array}{l}\text { sangat } \\
\text { layak/ } \\
\text { tinggi }\end{array}$ & $\begin{array}{l}\text { sangat } \\
\text { layak/ } \\
\text { tinggi }\end{array}$ & \multicolumn{2}{|c|}{ sangat layak/tinggi } \\
\hline
\end{tabular}

Data dari analisis hasil validasi akseptansi dapat dilihat pada Gambar 3 berikut.

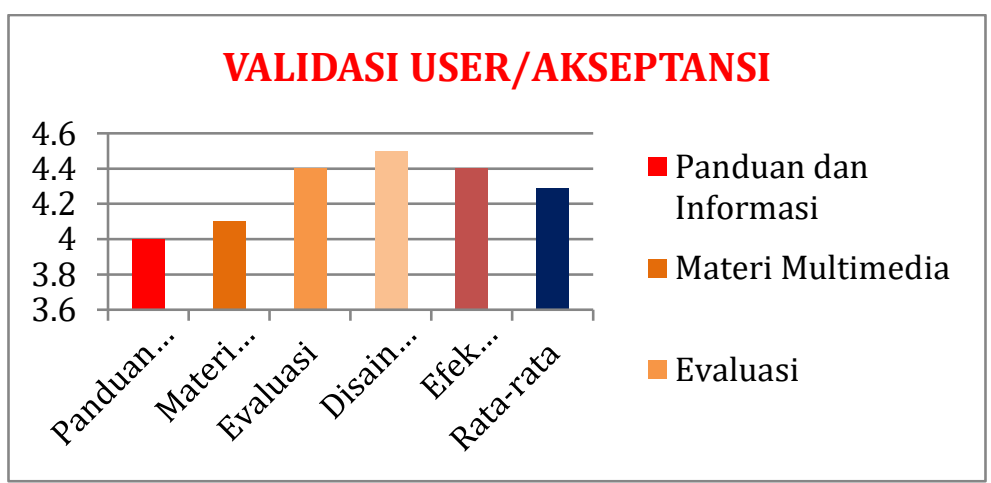

Gambar 3. Hasil Validasi User/Akseptansi

\section{Produk Akhir}

Tampilan produk akhir




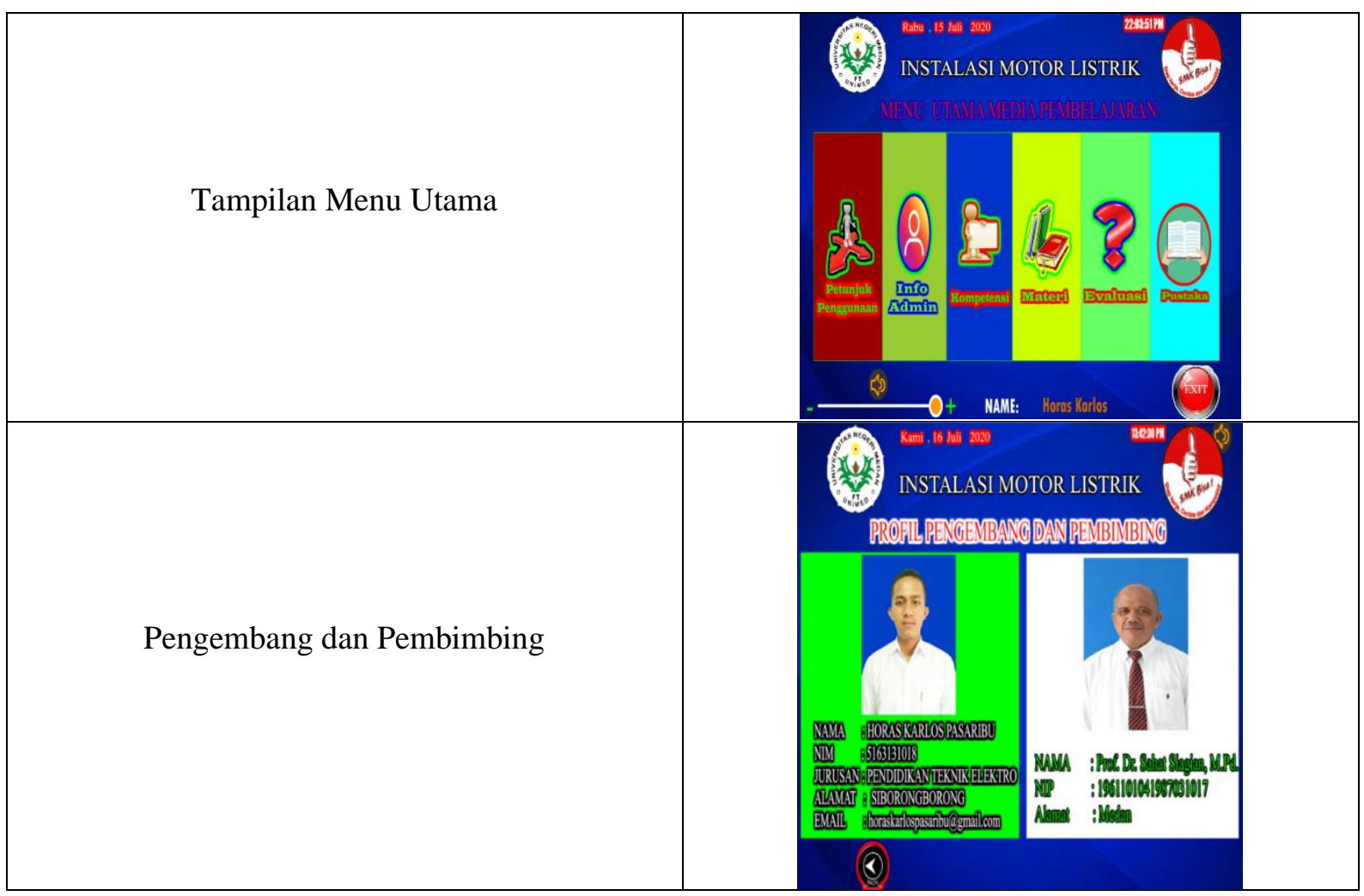

\section{Pembahasan}

Pengembangan multimedia pembelajaran interaktif berbasis Adobe Flash CS6 pada pelajaran instalasi motor listrik yakni perencanaan produk adalah dengan melakukan observasi ke sekolah SMK Swasta Dwiwarna Medan. Angket diberikan kepada peserta didik untuk mengetahui hal-hal yang perlu diperbaiki dalam proses pembelajaran instalasi motor listrik. Berdasarkan hasil observasi serta penyebaran angket, lalu menganalisis bahwa dalam proses pembelajaran media pembelajaran sangat perlu digunakan di dalam kelas untuk meningkatkan minat belajar atau memotivasi peserta didik. Tersedianya fasilitas penunjang proses pembelajaran seperti computer dan ruang computer, LCD/Proyektor, dapat dimanfaatkan dalam proses pembelajaran agar lebih menarik. Produk dikembangkan lalu divalidasi oleh dua ahli materi, dua ahli media pembelajaran dan satu user/akseptansi. Penelitian ini adalah media pembelajaran interaktif yang berbantu dari software Adobe flash CS6 pada mata pelajaran Instalasi Motor Listrik. Penelitian ini dilakukan dengan menggunakan prosedur pengembangan model ADDIE.

Setelah observasi kebutuhan dilakukan dan selesai, kemudian dilakukan pengumpulan data/informasi untuk mengetahui kebutuhan dari peserta didik terhadap produk yang ingin dikembangkan melalui penelitian dan pengembangan. Pengumpulan informasi dilakukan dengan wawancara terhadap pendidik dan peserta didik. Tahap selanjutnya mengumpulkan referensi yang berkaitan dengan media pembelajaran interaktif yang berbantu software Adobe flash CS6 pada mata pelajaran Instalasi Motor Listrik kelas XI.

\section{SIMPULAN}

Hasil kelayakan multimedia interaktif yang telah dilakukan oleh ahli materi adalah terkategori "sangat layak" dengan nilai rata-rata 4,4. Hasil validasi yang dilakukan oleh ahli media terkategori "sangat layak" dengan nilai rata-rata 3,35. Hasil validasi yang dilakukan oleh user/akseptansi terkategori "sangat layak". Dari hasil validasi yang dilakukan oleh lima validator didapatkan kesimpulan bahwa multimedia interaktif yang dikembangkan layak dipakai atau digunakan di jenjang SMK pada proses pembelajaran.

Multimedia pembelajaran interaktif dikembangkan dengan materi yang terbatas dan sesuai syaratsyarat pengembangan, selanjutnya perlu dikembangan lagi dengan materi, konten ataupun variasi yang lebih baik, kreatif dan menarik digunakan pada proses pembelajaran. Pada proses pembelajaran dengan menggunakan multimedia pembelajaran interaktif adobe flash CS6 perlu diuji keefektifannya dengan membandingkan software-software multimedia pembelajaran lainnya. 


\section{DAFTAR PUSTAKA}

Azhar, Arsyad. (2011). Media Pembelajaran. Jakarta: PT Raja Grafindo Persada.

Abdul Gofur. (2012). Desain Pembelajaran. Yogyakarta.

Branch, RM, \& Kopcha, TJ (2014). Model Desain Pembelajaran. Dalam Handbook Penelitian Tentang Komunikasi Pendidikan dan Teknologi.

Hanafi. (2018). Konsep Penelitian R\&D Dalam Bidang Pendidikan. ISSN: 2407-053X Banten.

Inung Diah Kurniawati, \& Sekreningsih Nita (2018). Media Pembelajaran Berbasis Multimedia Interaktif untuk Meningkatkan Pemahaman Konsep Mahasiswa. Journal of Computer and Information Technology, Vol.1, No.2. Unipma.

Mustaghfirin Amin, MBA. (2014). Instalasi Motor Listrik Kelas XI. Kementrian Pendidikan dan Kebudayaan Republik Indonesia.

Rusman. (2013). Belajar dan Pembelajaran Berbasis Komputer Mengembangkan Profesional Guru Abad 21. Bandung.

Setyosari, Punaji (2010) Metode Penelitian Pendidikan dan Pengembangan. Jakarta: Kencana.

Rudy Sumiharsono \& Hisbiyatul Hasanah (2017) Media Pembelajaran. Cetakan Pertama. CV. Pustaka Abadi.

Sriadhi. (2018). Instrumen Penilaian Multimedia Pembelajaran. Universitas Negeri Medan.

Sugiyono. (2016). Metode Penelitian dan Pengembangan Research and Development."Cet II (Bandung: Alfabeta 